\title{
One-step chromatographic method to purify $\alpha$-lactalbumin from whey for nanotube synthesis purposes
}

\author{
Clara Fuciños ${ }^{\mathrm{a}, \mathrm{b}, *}$, Pablo Fuciños ${ }^{\mathrm{c}}$, Natalia Estévez ${ }^{\mathrm{a}}$, Lorenzo M. Pastrana ${ }^{\mathrm{c}}$, Antonio A. Vicente ${ }^{\mathrm{b}}$, \\ María Luisa Rúa ${ }^{\mathrm{a}}$ \\ a Biotechnology Group, Department of Analytical Chemistry and Food Science, University of Vigo, As Lagoas s/n, 32004 Ourense, Spain \\ ${ }^{\mathrm{b}}$ Centre of Biological Engineering, University of Minho, Campus de Gualtar s/n, 4710-057 Braga, Portugal \\ ${ }^{\mathrm{c}}$ The International Iberian Nanotechnology Laboratory (INL), Avenida Mestre José Veiga s/n, 4715-330 Braga, Portugal
}

\section{A R T I C L E I N F O}

\section{Keywords:}

Whey proteins

$\alpha$-Lactalbumin

Purification

AEC chromatography

Nanotubes

Protein gels

\begin{abstract}
A B S T R A C T
A one-step anion-exchange chromatography method ( $\mathrm{NaCl}$ gradient elution on a DEAE Sepharose ${ }^{\mathrm{TM}}$ Fast Flow gel column) was developed to purify $\alpha$-lactalbumin ( $\alpha$-LA) from whey protein isolate. $\alpha$-LA nearly $100 \%$ pure (based on the total protein content) was obtained with a yield of about 39\%. Besides pure $\alpha$-LA, which was the main objective of this work, highly pure $\beta$-lactoglobulin was also obtained with a yield of about $59 \%$. The high purity of the obtained $\alpha$-LA samples allowed its use to synthesise protein nanotubes with excellent gelation properties for their use as food thickeners and bioactive carriers. The samples' purity degree obtained (based on the total protein content) was critical in the formation of proper nanotubes instead of random aggregates, which produced opaque and weak gels, less useful for food applications.
\end{abstract}

\section{Introduction}

Food nanotechnology has gained enormous interest during the last few years. Industries are particularly interested in developing smart and active delivery devices for a broad range of applications, from food packaging and safety to health and biomedical uses (Brody, Bugusu, Han, Sand \& McHugh, 2008). In particular, nanotube-based materials are now starting to have an impact on the food industry (Weiss, Takhistov \& McClements, 2006). Carbon nanotubes are popular as lowresistance conductors and catalytic reaction vessels, and as containers to release or protect valuable molecules. Although carbon nanotubes are not food-grade substances due to their potential toxicity for humans, some of their properties would find a place for food and health applications if they had characteristics such as biocompatibility, biodegradability, low cost and absence of toxicity.

Milk whey is a by-product of cheese manufacturing that is growing all over the world. In 2010, the global whey production was around 180 million tons (estimated as 9-fold the cheese production) (FAO, 2013; Guimarães, Teixeira \& Domingues, 2010). Whey removal and treatment is expensive. Nevertheless, whey content in high-value proteins (Tarhan \& Harsa, 2014) makes it not only a dairy by-product but also a valuable raw material.

$\beta$-Lactoglobulin ( $\beta$-LG, $18.4 \mathrm{kDa})$ and $\alpha$-lactalbumin ( $\alpha$-LA,
$14.2 \mathrm{kDa}$ ) are the two major proteins in whey. They are present in an $80: 20$ ( $\beta$-LG: $\alpha$-LA) ratio and together represent almost $70 \%$ of the total whey protein content (Walstra, Wouters \& Geurts, 2006). Both proteins are a valuable source of essential amino acids, although $\alpha$-LA has some properties that make it especially interesting for the industry. $\alpha$-LA contains high levels of tryptophan, which causes positive effects on consumers' well-being. Also purified fractions of $\alpha$-LA are used in infant formula to avoid the allergenic potential of $\beta$-LG (Toro-Sierra, Tolkach \& Kulozik, 2013). In addition to these properties, under appropriate conditions, $\alpha$-LA can self-assemble into nanotube structures (Graveland-Bikker, Fritz, Glatter \& De Kruif, 2006). These nanotubes have many potential applications (Ipsen \& Otte, 2007; Ramos et al., 2017). Within the food industry, encapsulation for controlled release of bioactive compounds or the protection of functional ingredients against degradation during food processing, storage, and usage are among the most promising applications. Basic applications for $\alpha$-LA nanotubes as thickening agents are also possible since linear structures are very efficient in increasing viscosity. Combining both applications makes these structures useful to be incorporated as fat substitutes into low-fat products, obtaining functional products with rheological properties similar to those of the full-fat products (mainly creaminess).

Despite the potential use of these materials, reports on their application are scarce (Fuciños et al., 2017). The production process of $\alpha$-LA

\footnotetext{
* Corresponding author at: Biotechnology Group, Department of Analytical Chemistry and Food Science, University of Vigo, As Lagoas s/n, 32004 Ourense, Spain.

E-mail address: clarafg@gmail.com (C. Fuciños).
} 
nanotubes is simple, and they can be easily produced in large quantities. However, the synthesis of nanotubes requires highly pure $\alpha$-LA, which is costly to produce, therefore limiting its use to only high valueadded applications.

The development of cheaper purification methods will boost the incomes of dairy industries, allowing not only to reduce the generation of wastes but also to reuse them obtaining a new high added value product. However, a major challenge is developing an easily scalable, economical process capable of providing high purity and yield enough for subsequent applications.

Several methods have been developed during the last decades to purify whey proteins. In the literature, we can find a wide variety of methods with common pre-treatments to obtain a whey protein isolate (WPI) or a whey protein concentrate (WPC), that includes different steps for removing fat, precipitate the major whey proteins to separate the target proteins from other proteinic contaminants at the end. However, in general, commercial WPI or WPC was used to optimise the methods. New methods were developed based on successive precipitations and separations by microfiltration and/or ultrafiltration (Alomirah \& Alli, 2004; Arunkumar \& Etzel, 2014; Toro-Sierra et al., 2013), selective enzymatic hydrolysis (Konrad \& Kleinschmidt, 2008; Lisak, Toro-Sierra, Kulozik, Bozanic \& Cheison, 2013), selective adsorption on hydroxyapatite microbeads (Cetinkaya \& Akkaya, 2016), processes applying supercritical carbon dioxide (Bonnaillie \& Tomasula, 2012; Yver, Bonnaillie, Yee, Mcaloon \& Tomasula, 2012), or methods based on two-phase systems (Sivakumar \& Iyyaswami, 2015). These methods involve multiple steps to achieve high purity fractions (Table 1), which could hinder their implementation. The simplest and most common methods are those that involve chromatographic approaches. However, the reported chromatographic methods to obtain highly pure $\alpha$-LA always consist of at least two steps (El-Sayed \& Chase, 2010; Neyestani, Djalali \& Pezeshki, 2003; Tarhan \& Harsa, 2014), or even three steps (Pilbrow, Bekhit \& Carne, 2016). In alternating order, these steps are usually gel filtration chromatography (also known as size exclusion chromatography), where proteins are separated by their molecular size, and ion exchange chromatography, where proteins are separated as a function of their overall charge. In the last chromatographic method, proteins are selectively eluted using a salt gradient (Neyestani et al., 2003) or a pH gradient (Tarhan \& Harsa, 2014). Only a few works describing the application of a single chromatographic method are found in the literature (Geng, Tolkach, Otte, \& Ipsen, 2015; Liang, Chen, Chen, \& Chen, 2006; Mao et al., 2017), whose results (Table 1) we pretend to improve.

In this paper, we propose a one-step purification method based on ion-exchange chromatography to obtain highly pure $\alpha$-LA fractions. Subsequently, we demonstrate that these $\alpha$-LA fractions are suitable for the synthesis of protein nanotubes for food applications.

\section{Material and methods}

\subsection{Standards and chemicals}

WPI and $\alpha$-LA, were kindly supplied by Davisco Foods International, Inc. (Eden Prairie, MN, USA). $\beta$-LG from bovine milk ( $>90 \%$ ), bovine serum albumin (BSA, $\geq 98.0 \%$ ), trifluoroacetic acid CHROMASOLV ${ }^{\circledR}$, for HPLC (TFA, $\geq 99.0 \%$ ), acetonitrile CHROMASOLV ${ }^{\circledR}$ Plus, for HPLC (ACN, $\geq 99.9 \%$ ), Coomassie Brilliant Blue R-250 (technical grade) and 2-mercaptoethanol for electrophoresis (>98\%) were purchased from Sigma-Aldrich (Munich, Germany). TRIS buffer (tris-(hydroxymethyl)-aminomethane, extra pure) was from Scharlau. Hydrochloric acid $(\mathrm{HCl}, 37 \%)$, sodium chloride $(\mathrm{NaCl})$, sodium dihydrogen phosphate anhydrous $\left(\mathrm{NaH}_{2} \mathrm{PO}_{4}\right)$, disodium hydrogen phosphate anhydrous $\left(\mathrm{Na}_{2} \mathrm{HPO}_{4}\right)$, sodium azide (99\%), sodium dodecyl sulfate (SDS), glycerol and bromophenol blue were from Panreac (Barcelona, Spain).

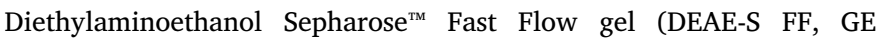
Healthcare Bio-Sciences AB, Uppsala, Sweden). BCA Protein Assay Kit was purchased from Pierce (Rockford, IL, USA). Acrylamide/Bis 30\% (29:1) and broad range SDS-PAGE molecular weight standards were purchased from Bio-Rad Laboratories (Watford, UK). Serine protease from Bacillus licheniformis (BLP) was gently supplied by Novozymes A/ $\mathrm{S}$ (Bagsværd, Denmark). Manganese (II) chloride tetrahydrate $\left(\mathrm{MnCl}_{2} \cdot 4 \mathrm{H}_{2} \mathrm{O}\right)$ was from Merck (Darmstadt, Germany). Sodium cacodylate EM and glutaraldehyde EM 25\% were purchased from TAAB (Reading, UK).

\subsection{Preparation of the whey protein samples}

Samples for the purification processes were prepared by dissolving WPI at different concentrations, depending on the experiment, in $25 \mathrm{mM}$ Tris- $\mathrm{HCl}$ buffer ( $\mathrm{pH} 7.5$ at $\left.25^{\circ} \mathrm{C}\right)$. The solutions were then filtered through a $0.22 \mu \mathrm{m}$ filter. The obtained purified samples were prepared in the same way for their further characterisation.

\subsection{Whey proteins purification by anion-exchange chromatography}

In a first part of our research (Fig. 1), to purify $\alpha$-LA from WPI, the anion-exchange chromatography (AEC) conditions were optimised by using a HiPrep ${ }^{\mathrm{TM}}$ 16/10 DEAE FF column (volume: $20 \mathrm{~mL}$, GE Healthcare Bio-Sciences AB, Uppsala, Sweden) coupled to an ÄKTA Purifier 10 (GE Healthcare Bio-Sciences AB, Uppsala, Sweden) following the instructions provided by the manufacturer. The column was equilibrated

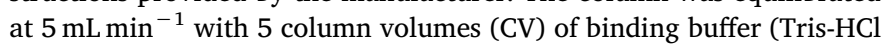
$25 \mathrm{mM}$ buffer, $\mathrm{pH} 7.5$ at $25^{\circ} \mathrm{C}$ ). Then, an appropriate amount of protein was loaded onto the column at a flow rate of $1 \mathrm{~mL} \mathrm{~min}{ }^{-1}$. The column was washed at $4 \mathrm{~mL} \mathrm{~min}^{-1}$ with $5 \mathrm{CV}$ of binding buffer, and then eluted in four steps: (1) $3 \mathrm{CV}$ of $5 \%$ elution buffer (Tris- $\mathrm{HCl} 25 \mathrm{mM}$ buffer, $\mathrm{pH}$ 7.5 at $25^{\circ} \mathrm{C}$, with $\mathrm{NaCl} 1 \mathrm{M}$ ), (2) $20 \mathrm{CV}$ increasing the elution buffer from 5 to $11 \%$, (3) $10 \mathrm{CV}$ increasing the elution buffer from 11 to $35 \%$, and (4) $3 \mathrm{CV}$ of $100 \%$ elution buffer. Protein elution was monitored by absorbance at $280 \mathrm{~nm}$. The collected fractions were concentrated (3.75x) and analysed by reverse-phase high-performance liquid chromatography (RP-HPLC).

In a subsequent part of the research the one-step purification process was scaled-up (Fig. 1). A chromatography was conducted, loading an appropriate amount of protein at a flow rate of $2.5 \mathrm{~mL} \mathrm{~min}^{-1}$ onto a DEAE-S FF gel packed in a column with $5 \mathrm{~cm}$ of length and $5 \mathrm{~cm}$ of internal diameter (volume: $98 \mathrm{~mL}$ ). Equilibration, elution and detection conditions were kept the same as described above for the optimisation with the HiPrep DEAE FF 16/10 column. The collected fractions were desalted by diafiltration with MilliQ water using Ultracel $^{\circledast} 10 \mathrm{kDa}$ molecular weight cut-off (MWCO) membranes (Millipore, MA, USA) mounted on an Amicon ${ }^{\circledR}$ model 8200 stirred cell (model 8200; Millipore, CA, USA) under 40-psi pressure of nitrogen gas at room temperature, until the conductivity reached $\sim 0.2 \mathrm{mS}$. The retentate was then freeze-dried for further analysis.

\subsubsection{Optimisation of the protein loading capacity}

WPI samples with different protein concentration were prepared in binding buffer. The same volume of WPI samples and DEAE-S FF gel, also equilibrated in binding buffer, were placed in microtubes. After that, the microtubes were gently mixed in a rotatory shaker for $15 \mathrm{~min}$ and then centrifuged at $300 \times g$ for $10 \mathrm{~min}$. After that, the supernatant was removed from samples and analysed by BCA Protein Assay Kit to obtain the not binding protein onto the DEAE-S FF gel $\left(N B P, \mathrm{mg} \mathrm{mL}^{-1}\right)$. The percentage of not bound protein $(\% N B P)$ was calculated as follows:

$\% N B P=\frac{N B P}{L P_{i}} \times 100$

where $L P_{i}$ is the initial amount of loaded protein in $\mathrm{mg}$ per $\mathrm{mL}$ of DEAES FF gel. \%NBP is plotted against $L P_{i}$ (Fig. 2) and these experimental data were fitted with a logistic equation, adapted from Vázquez, Docasal, Prieto, González, and Murado (2008), to calculate the protein 


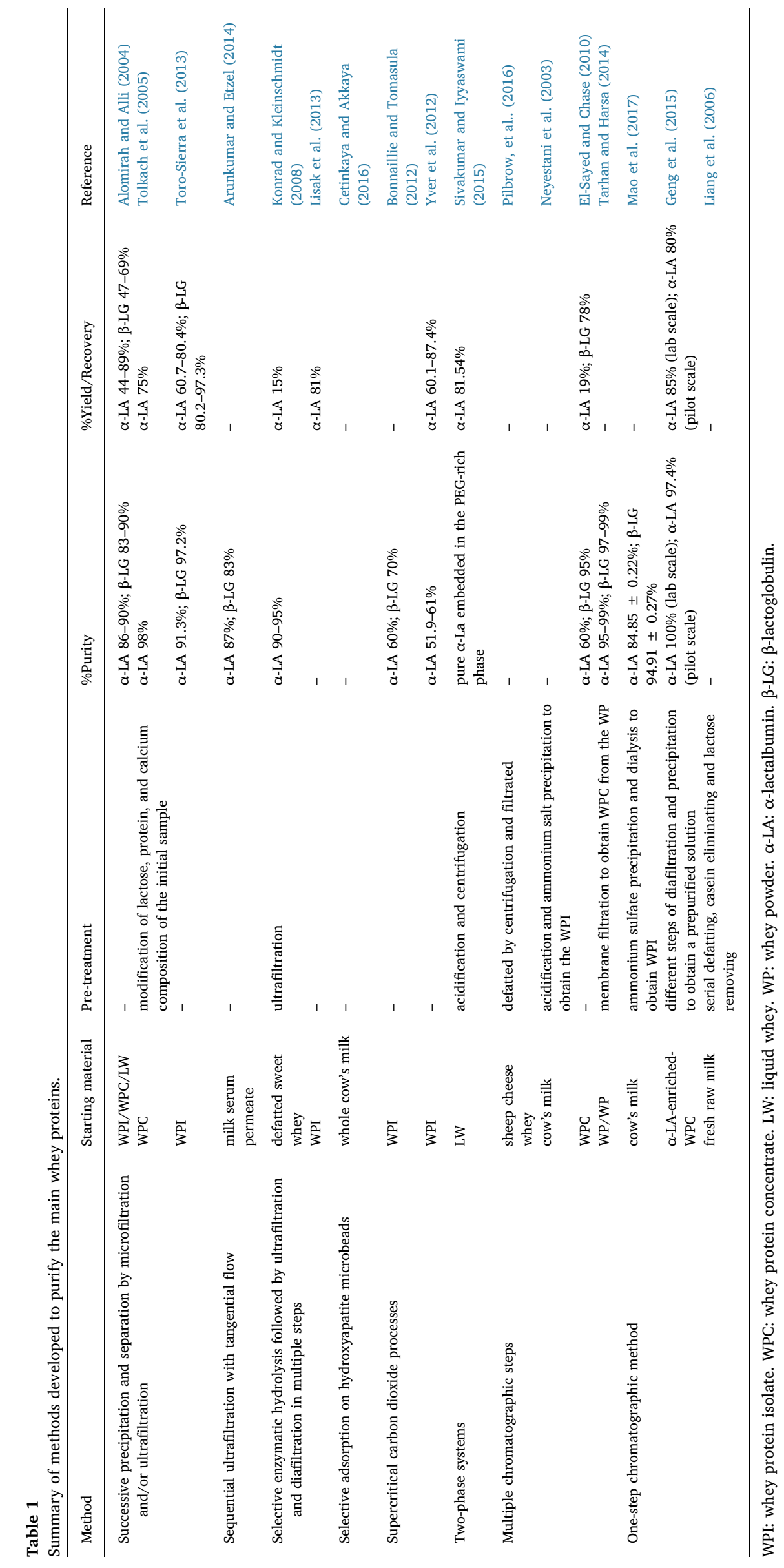




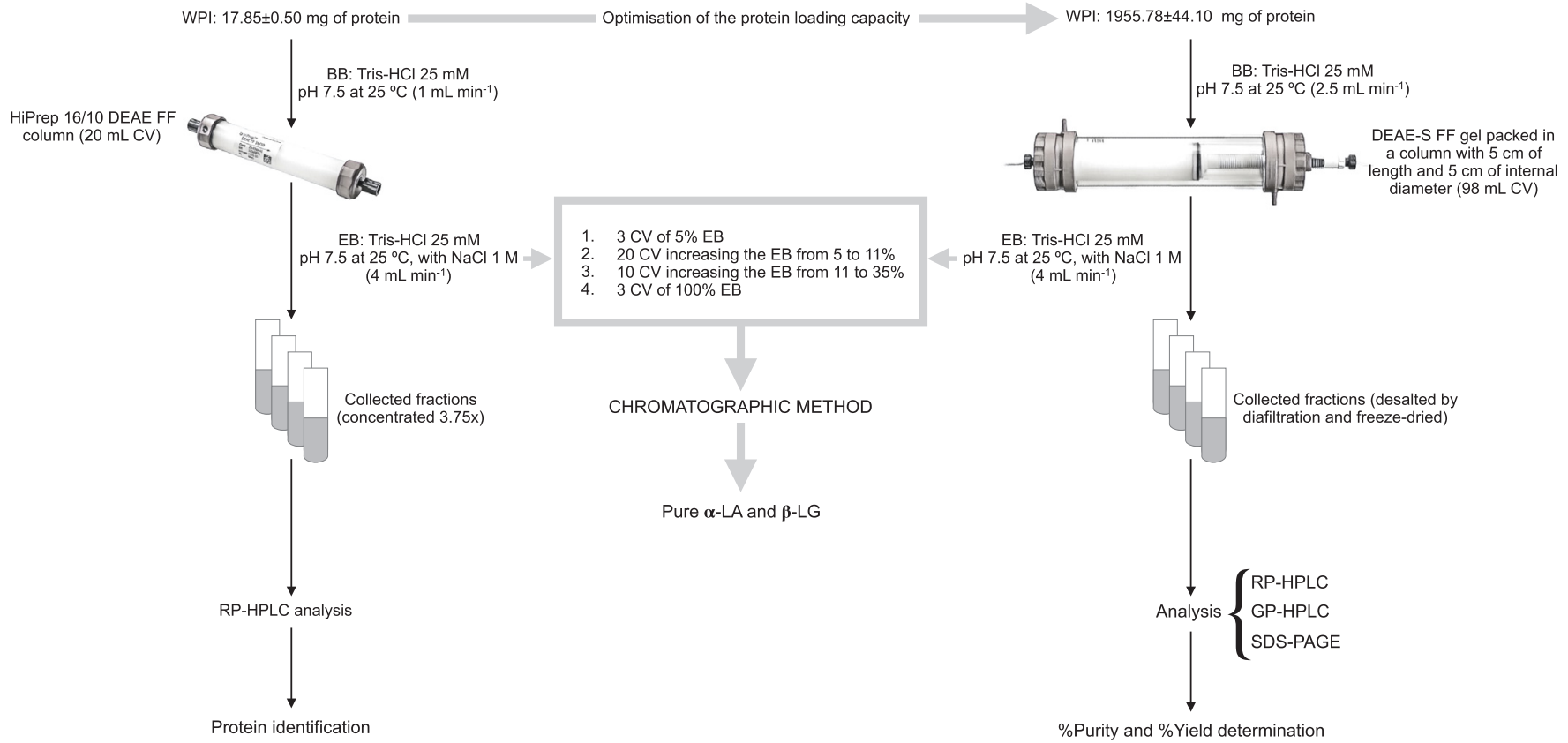

Fig. 1. Experimental design for the purification method development. BB: Binding buffer. EB: Elution buffer. WPI: whey protein isolate. $\alpha$-LA: $\alpha$-lactalbumin. $\beta$-LG: $\beta$ lactoglobulin.

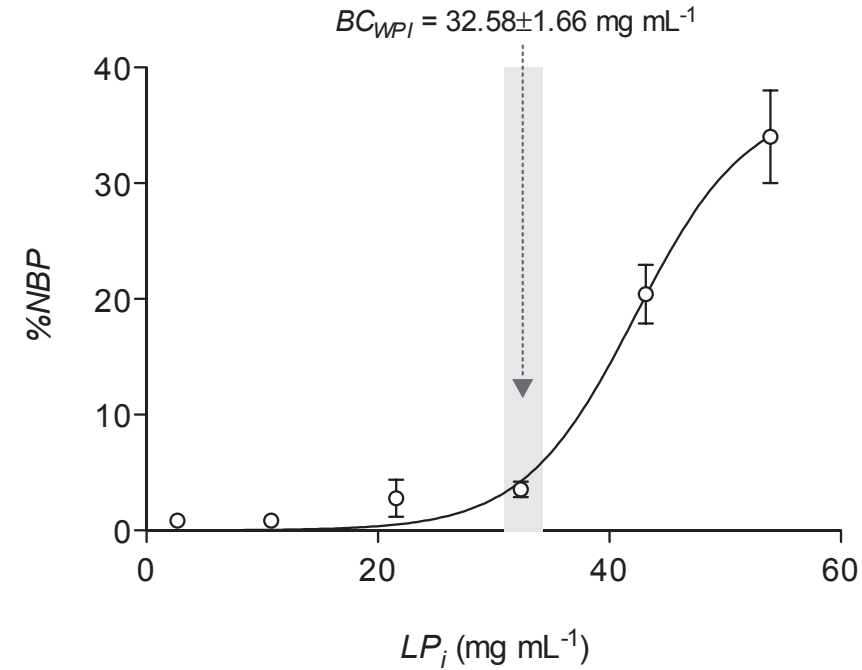

Fig. 2. Percentage of not bound protein (\%NBP) represented against the initial amount of loaded protein $\left(L P_{i}\right)$, in $\mathrm{mg}$ per $\mathrm{mL}$ of gel. Whey protein binding capacity $\left(B C_{W P I}, \mathrm{mg} \mathrm{mL}^{-1}\right.$ ) of DEAE-S FF gel was calculated after fitting (line) Eq. (2) to the experimental data (symbols).

binding capacity $\left(B C_{W P I}, \mathrm{mg} \mathrm{mL}^{-1}\right)$ :

$\% N B P=\frac{N B P_{\max }}{1+e^{2+\frac{4 \cdot v_{\max }}{N B P_{\max }}\left(B C_{W P I}-L P_{i}\right)}}$

where $N B P_{\max }$ was the maximum not bound protein $\left(\mathrm{mg} \mathrm{mL}^{-1}\right)$ and $v_{\max }$ was the maximum protein elution rate $\left(\mathrm{mL} \mathrm{mg}^{-1}\right)$.

\subsection{Whey protein identification and quantification}

Individual protein identification and quantification by RP-HPLC was performed following the method developed by Estévez et al. (2017), using an Agilent 1200 system equipped with a Variable Wavelength Detector (Agilent Technologies, Palo Alto, CA, USA). Separation was performed employing an $\mathrm{ACE}^{\circledR} \mathrm{C} 18$ column $(4.6 \mathrm{~mm} \times 250 \mathrm{~mm}, 5 \mu \mathrm{m}$, $300 \AA$ ) with the column oven kept at $30^{\circ} \mathrm{C}$. The flow rate was $0.7 \mathrm{~mL} \mathrm{~min}^{-1}$, the injection volume was $20 \mu \mathrm{L}$ and the detection wavelength of $220 \mathrm{~nm}$. Mobile phase A was $0.1 \%(\mathrm{v} / \mathrm{v}$ ) TFA in Milli-Q water, and mobile phase B was $0.1 \%(\mathrm{v} / \mathrm{v})$ TFA in $100 \%(\mathrm{v} / \mathrm{v})$ ACN. Mobile phase A was maintained at $100 \%$ for $5 \mathrm{~min}$, and then it decreased linearly to $50 \%$ over $50 \mathrm{~min}$. Mobile phase B was increased linearly to $100 \%$ over the next $2.5 \mathrm{~min}$ and then was maintained at $100 \%$ of mobile phase B for another $2.5 \mathrm{~min}$. Finally, mobile phase A was increased linearly to $100 \%$ over $5 \mathrm{~min}$, and the column was reequilibrated at $100 \%$ of mobile phase A for a further $5 \mathrm{~min}$.

Commercial standards of $\alpha$-LA, $\beta$-LG and BSA were used to determine their retention times. Calibration curves were constructed with these standards, which resulted highly linear within the concentration range: $0.1-3.0 \mu \mathrm{g} \mathrm{mL}^{-1}$ for $\alpha$-LA and $\beta$-LG, and $0.1-4.0 \mu \mathrm{g} \mathrm{mL}^{-1}$, for BSA.

The purity of fractions obtained from AEC was determined as follows:

$\%$ Purity $=\frac{C_{R P-H P L C}}{C_{T}} \times 100$

where $C_{R P \text {-HPLC }}$ is the concentration of each protein $\left(\mathrm{mg} \mathrm{mL}^{-1}\right)$ determined by RP-HPLC. $C_{T}$ is the total solute concentration $\left(\mathrm{mg} \mathrm{mL}^{-1}\right)$, for the "\% purity based on total solute"; or the total protein concentration ( $\mathrm{mg} \mathrm{mL}^{-1}$ ) (measured using the BCA Protein Assay Kit using BSA as standard), for the "\% purity based on total protein".

Individual protein identification was also performed by gel filtration-high performance liquid chromatography (GF-HPLC) as described by Croguennec, O'Kennedy, and Mehra (2004). A TSKgel G3000SWXL ( $5 \mu \mathrm{m}, 7.8 \mathrm{~mm} \times 300 \mathrm{~mm}$; Tosoh Bioscience, Grove City, OH, USA) column coupled to an Agilent 1200 system equipped with a Variable Wavelength Detector (Agilent Technologies, Palo Alto, CA, USA) was used to analyse the molecular weight (MW) of the collected fractions. The column temperature was not controlled; the injection volume was $20 \mu \mathrm{L}$ and the detection wavelength of $278 \mathrm{~nm}$. The isocratic elution was performed at a flow rate of $0.8 \mathrm{~mL} \mathrm{~min}^{-1}$ during $15 \mathrm{~min}$, employing phosphate $20 \mathrm{mM}$ ( $\mathrm{pH} 7.2$ at $25^{\circ} \mathrm{C}$ ) buffer with sodium azide 
$(0.05 \%, w / v)$. Commercial standards of $\alpha$-LA (14.2 kDa), $\beta$-LG $(18.4 \mathrm{kDa})$ and BSA (66 kDa) were used to determine their retention times.

\subsection{Whey protein electrophoresis analysis}

Sodium dodecyl sulfate-polyacrylamide gel electrophoresis (SDSPAGE) was performed, according to Laemmli (1970), using a $10 \%$ and $15 \%$ acrylamide separating gels and $4 \%$ stacking gels in a vertical slab mini-gel apparatus (Model SE 250; Amersham Biosciences, Sweden) at $40 \mathrm{~mA}$ for $1 \mathrm{~h}$. Protein samples were $2 \mathrm{x}$ diluted with sample buffer (125 mM Tris/HCl buffer pH 6.8, 4\% SDS (w/v), 20\% glycerol (v/v), $2 \%$ of 2 -mercaptoethanol $(\mathrm{w} / \mathrm{v})$ and $0.002 \%$ bromphenol blue $(\mathrm{w} / \mathrm{v}))$. Then, the mixture was stirred in a vortex, boiled at $100{ }^{\circ} \mathrm{C}$ for $5 \mathrm{~min}$ and loaded onto the gel. After migration, gels were stained for protein detection with Coomassie Brilliant Blue R-250 following standard procedures (Morrissey, 1981). Broad range SDS-PAGE MW standards from Bio-Rad used as markers included: myosin (200 kDa), $\beta$-galactosidase (116.25 kDa), phosphorylase B (97.4 kDa), BSA (66.2 kDa), ovalbumin (45 kDa), carbonic anhydrase (31 kDa), trypsin inhibitor $(21.5 \mathrm{kDa})$, lysozyme $(14.4 \mathrm{kDa})$, and aprotinin $(6.5 \mathrm{kDa})$. WPI and commercial standards of $\alpha$-LA and $\beta$-LG were also analysed.

ImageJ $1.48 \mathrm{v}$ (National Institutes of Health, USA) was used for gel analysis and to estimate the protein the MW and the protein purity.

\subsection{Nanotube synthesis}

Nanotubes were prepared following the method described in Graveland-Bikker, Ipsen, Otte, and De Kruif (2004). Briefly, protein sample powder was dissolved $\left(30 \mathrm{~g} \mathrm{~L}^{-1}\right)$ in buffer $75 \mathrm{mM}$ Tris- $\mathrm{HCl}(\mathrm{pH}$ 7.5). $\mathrm{MnCl}_{2} \cdot 4 \mathrm{H}_{2} \mathrm{O}$ was added to the solution at $2.79 \%(\mathrm{w} / \mathrm{w})$, with respect to the amount of protein sample, to provide a divalent ion for the nanotube formation. To begin the hydrolysis 4\% BLP (w/w), with respect to the amount of protein sample was added. After stirring, the solution was immediately filtered using a $0.1 \mu \mathrm{m}$ filter low protein binding from Millipore Ibérica, S.A. (Madrid, Spain) and incubated at $55^{\circ} \mathrm{C}$ in a thermostatic bath for $3 \mathrm{~h}$.

\subsection{Nanotube analysis by transmission electron microscopy (TEM)}

$\alpha$-LA nanotubes samples were diluted 1:1 with a fixative $(1.5 \%$ glutaraldehyde in $0.1 \mathrm{M}$ sodium cacodylate buffer) and stored at $4{ }^{\circ} \mathrm{C}$ until their analysis. Samples were prepared by the conventional negative staining method. A Formvar layer on a copper grid was coated with carbon, immersed in $5 \mu \mathrm{L}$ of $5 \mathrm{x}$ diluted sample, and blotted after $1 \mathrm{~min}$. Then the copper grid was washed with water for $1 \mathrm{~min}$ and subsequently blotted, to remove the excess of protein material. After that, the copper grid was immersed for $1 \mathrm{~min}$ in $3 \%(\mathrm{w} / \mathrm{w})$ uranyl acetate to enhance the contrast and blotted again. Samples were then dried for $1 \mathrm{~h}$ in a desiccator. Micrographs were obtained with a JEOL JEM-1010 $100 \mathrm{kV}$ high contrast transmission electron microscope.

\section{Results and discussion}

\subsection{Whey proteins purification by anion-exchange chromatography}

A HiPrep ${ }^{\mathrm{TM}} 16 / 10$ DEAE FF column was used to optimise the anionexchange chromatographic method (AEC) (Fig. 1). The column was loaded with $17.85 \pm 0.50 \mathrm{mg}$ of protein (WPI). The results of the optimisation are shown in Fig. 3A. Each collected fraction from this chromatography was analysed by RP-HPLC. The peak area for the main whey proteins ( $\alpha$-LA, $\beta$-LG and BSA) was depicted against the elution volume (Fig. 3B) in order to know the composition for each peak obtained with the AEC (Fig. 3A). The results showed that the most intense peaks corresponded to the $\alpha$-LA (peak 1 in Fig. 3A) and $\beta$-LG (peak 2 in Fig. 3A), and only some residual amount of BSA appeared co-eluting

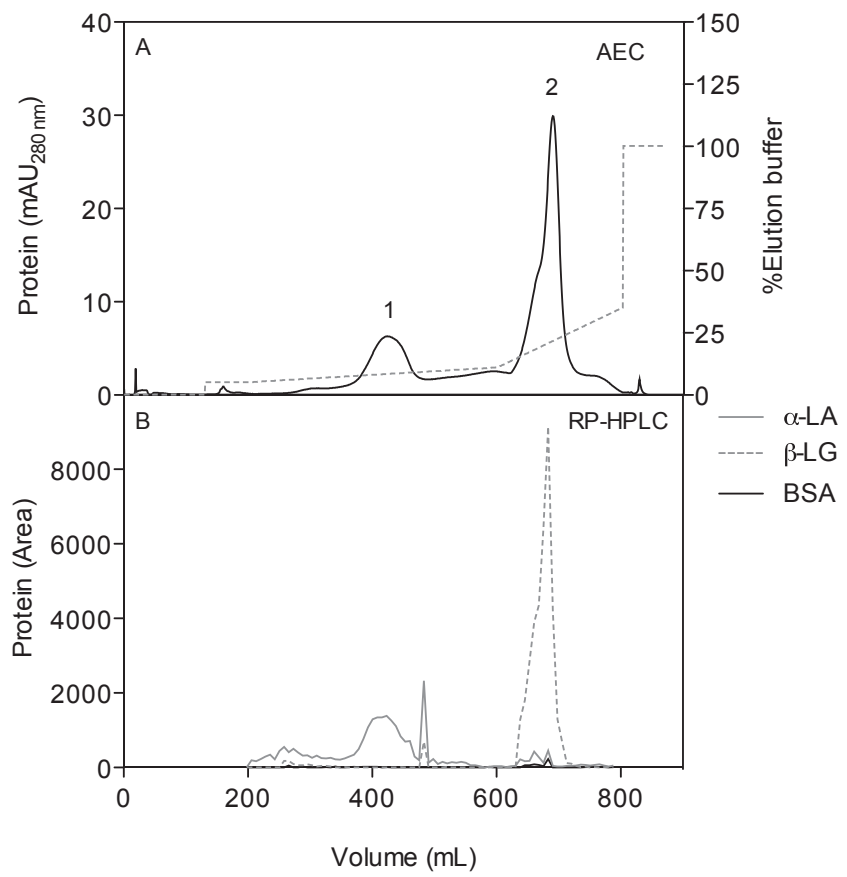

Fig. 3. (A) Purification by AEC on a $20 \mathrm{~mL} \mathrm{HiPrep}^{\text {TM }} 16 / 10$ DEAE FF column. Sample: whey protein isolate (17.85 $\pm 0.50 \mathrm{mg}$ of protein) dissolved in $25 \mathrm{mM}$ Tris-HCl buffer ( $\mathrm{pH} 7.5$ at $25^{\circ} \mathrm{C}$ ). Chromatography conditions: binding buffer: $25 \mathrm{mM}$ Tris- $\mathrm{HCl}$ buffer, pH 7.5 at $25^{\circ} \mathrm{C}$; elution buffer: $25 \mathrm{mM}$ Tris-HCl buffer, $\mathrm{pH} 7.5$ at $25^{\circ} \mathrm{C}$ with $1 \mathrm{M} \mathrm{NaCl}$; elution flow rate: $4 \mathrm{~mL} / \mathrm{min}$; fractions: $7.5 \mathrm{~mL}$. Continuous line: protein. Dashed line: \% elution buffer. (B) RP-HPLC analysis of the protein fractions isolated from AEC. $\alpha$-LA: $\alpha$-lactalbumin. $\beta$-LG: $\beta$-lactoglobulin.

with these peaks. However the amount of protein obtained with the HiPrep $^{\mathrm{TM}} 16 / 10$ DEAE FF column was not enough to calculate purification factors (PF), so it was necessary to increase the amount of protein initially loaded onto the column.

A new anion-exchange chromatography was carried out to scale-up the purification process (Fig. 1). In order to maximise the amount of protein loaded, the protein (WPI) binding capacity of DEAE-S FF gel $\left(B C_{W P I}\right)$ was determined, which was $32.58 \pm 1.66 \mathrm{mg}$ of protein per mL of DEAE-S FF gel (Fig. 2). To avoid achieving the limit of the binding capacity, no more than $20 \mathrm{mg} \mathrm{mL}^{-1}$ was loaded $(1955.78 \pm 44.10 \mathrm{mg}$ of protein loaded onto a $98 \mathrm{~mL}$ DEAE-S FF gel column). The elution method was the same previously optimised, as described in the Materials and Methods section. The chromatogram obtained is shown in Fig. 4A. Different fractions from each peak were analysed by RP-HPLC to identify their composition, which resulted in being, in a higher proportion, $\alpha$-LA for peak 1 and 2, and $\beta$-LG for peak 3 . Then, the fractions corresponding to the same peak (grey shaded in Fig. 4A) were pooled, diafiltrated and freeze-dried. The purity and composition of these peaks were then further analysed by RP-HPLC (Fig. 4B and Table 2), GF-HPLC (Fig. 4C) and SDS-PAGE (Fig. 5). No protein aggregates were detected in the wells and stacking gel, so these were removed in Fig. 5.

For AEC-peak 1, in both chromatograms, RP-HPLC and GF-HPLC (Fig. 4B and C), BSA and $\beta$-LG peaks were almost imperceptible. The $\alpha$ LA peak appeared with another peak close to it, which could not be BSA or $\beta$-LG as could be seen in HPLC chromatograms (Fig. 4B and 4C). Also on SDS-PAGE gel (Fig. 5), besides the band (14.41 kDa) corresponding to $\alpha$-LA, another band appeared $(18.31 \mathrm{kDa})$ slightly above the band corresponding to $\beta$-LG. This band could correspond to glycomacropeptide (GMP $\sim 6.7 \mathrm{kDa}$ ), another whey protein, which usually appears as a trimer on SDS-PAGE gels (Neelima, Sharma, Rajput \& Mann, 2013). In light of the results, peak 1 protein composition was mostly $\alpha$-LA with 

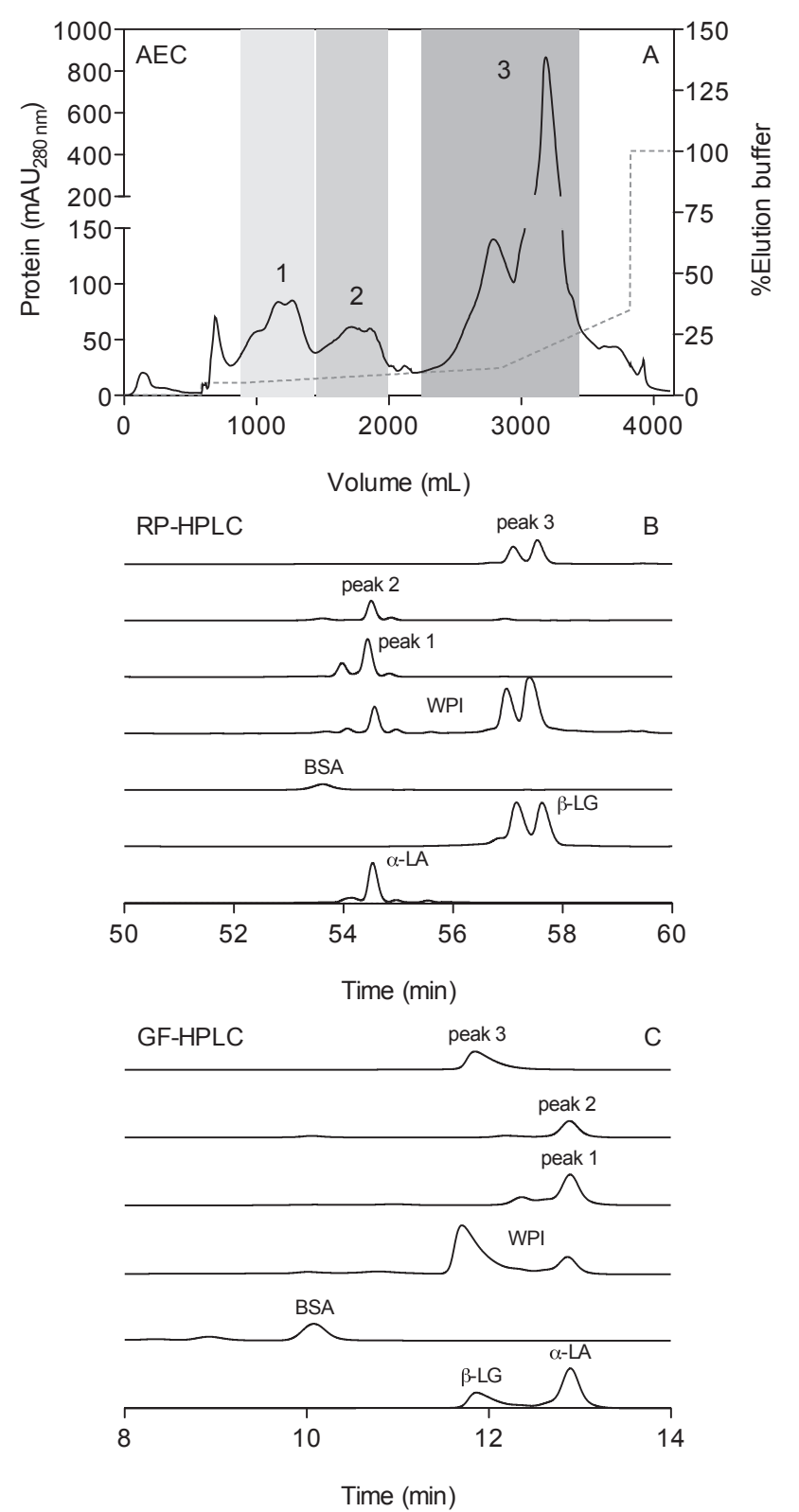

Fig. 4. (A) Purification by AEC on a $98 \mathrm{~mL}$ DEAE-S FF gel column. Sample: whey protein isolate $(1955.78 \pm 44.10 \mathrm{mg}$ of protein) dissolved in $25 \mathrm{mM}$ Tris$\mathrm{HCl}$ buffer ( $\mathrm{pH} 7.5$ at $25^{\circ} \mathrm{C}$ ). Chromatography conditions: binding buffer: $25 \mathrm{mM}$ Tris-HCl buffer, $\mathrm{pH} 7.5$ at $25^{\circ} \mathrm{C}$; elution buffer: $25 \mathrm{mM}$ Tris-HCl buffer, pH 7.5 at $25^{\circ} \mathrm{C}$ with $1 \mathrm{M} \mathrm{NaCl}$; elution flow rate: $4 \mathrm{~mL} / \mathrm{min}$; fractions: $13.5 \mathrm{~mL}$. Continuous line: protein. Dashed line: \% elution buffer. (B) RP-HPLC chromatograms of the main peaks collected during AEC, WPI (whey protein isolate) and $\alpha$-LA ( $\alpha$-lactalbumin), $\beta$-LG ( $\beta$-lactoglobulin) and BSA (bovine serum albumin) standards. (C) GF-HPLC chromatograms of the main peaks collected during AEC, WPI and $\alpha$-LA, $\beta-\mathrm{LG}$ and BSA standards.

a small proportion of another protein, probably GMP. The purity of $\alpha$ LA (based on total solute) in peak 1 was $78.22 \pm 2.66 \%$ (Table 2).

For AEC-peak 2, in addition to $\alpha$-LA, very small peaks of BSA and $\beta$ LG appeared in both RP-HPLC and GF-HPLC chromatograms (Fig. 4B and C). Three clear bands appeared on an SDS-PAGE gel (Fig. 5): at $63.21 \mathrm{kDa}$, which corresponds to BSA; at $16.54 \mathrm{kDa}$, which corresponds to $\beta$-LG; and at $14.25 \mathrm{kDa}$, which corresponds to $\alpha$-LA. The purity of $\alpha$ LA (based on total solute) in peak 2 was lower $(60.67 \pm 2.76 \%)$ than in peak 1 (Table 2). Also, the method here described, although developed to purify $\alpha$-LA, allowed to obtain $\beta$-LG (peak 3 in Fig. 4A) with an $86.09 \pm 4.78 \%$ purity (based on total solute) (Table 2 ).

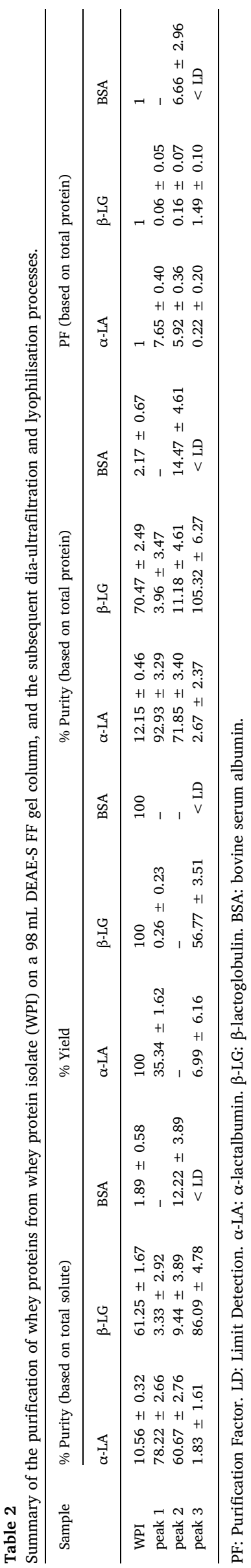




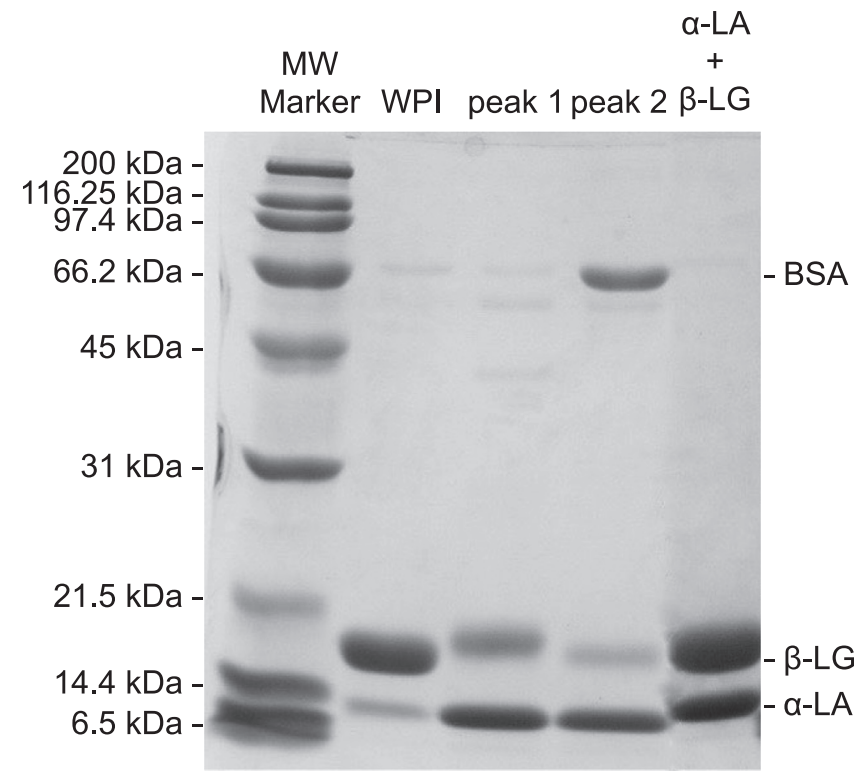

Fig. 5. SDS-PAGE profiles of the main peaks collected during the AEC of whey protein isolate (WPI) on a $98 \mathrm{~mL}$ DEAE-S FF gel column. Whey protein isolate (WPI), and $\alpha$-lactalbumin ( $\alpha$-LA) and $\beta$-lactoglobulin ( $\beta$-LG) were also loaded as standards. Bovine serum albumin (BSA) was loaded with the molecular weight marker. Staining: Coomassie Brilliant Blue R-250.

Specific yields of the $\alpha$-LA and $\beta$-LG purification from WPI on the $98 \mathrm{~mL}$ DEAE-S FF gel column were $35.34 \pm 1.62 \%$ and $56.77 \pm 3.51 \%$ (Table 2), respectively. These values are similar and in some cases even higher than those in previously reported attempts to purify $\alpha$-LA and $\beta$-LG (Table 1 ). It should also be noted that the method described in this paper is a one-step process, while most of the chromatographic methods for purification of whey proteins found in the literature include a separation step by gel-filtration chromatography (GFC). Although GFC improves sample purity, it restricts the process up-scalability due to the low loading capacity of gel filtration columns.

Mao et al. (2017) presented a work to separate $\alpha$-LA and $\beta$-LG from cow's milk in one chromatographic step with previous ammonium sulphate precipitation and dialysis to obtain a whey protein isolate. They achieve purities (based on total protein) of $84.85 \pm 0.22 \%$ and $94.91 \pm 0.27 \%$ for $\alpha$-LA and $\beta$-LG respectively, lower than our results. They indicate that the yield obtained was $330 \pm 2 \mathrm{mg}$ and $598 \pm 11 \mathrm{mg}$ for $\alpha$-LA and $\beta$-LG respectively when they start with $250 \mathrm{~mL}$ of whey. However, they did not indicate the protein concentration on that whey, so we cannot compare the yields.

Geng et al. (2015) described an interesting work where $\alpha$-LA was purified from $\alpha$-LA-enriched-WPC treated with different steps of diafiltration and precipitation to obtain a prepurified solution. Then a chromatographic step was applied achieving good results (Table 1). However, the purification factor (PF: 1.75) was very low compared to our work, taking into account that the $\alpha$-LA-enriched-WPC used as starting sample contains $57 \%$ of $\alpha$-LA against of our result of 7.65 (Table 2). This higher content on $\alpha$-LA in the initial sample probably favours these higher values of recovery. Tolkach, Steinle and Kulozik (2005) described an effective method to obtain pure $\alpha$-LA by selective denaturation of $\beta$-LG with a high degree of purity and recovery of $75 \%$ (Table 1). However, the method is very dependent on the initial sample composition. Toro-Sierra et al. (2013) fractionated WPI to obtain pure $\alpha$-LA and $\beta$-LG following multiple steps in pilot plant scale with good values of purity and yields (Table 1 ). The PF, taking into account the $\%$ of $\alpha$-LA in the initial sample (20.2\%), was 4.52 , i.e., lower than that obtained in the present work (7.65, Table 2).

For the synthesis of nanoparticles from whey proteins, it is important not only their purity referred to the total sample composition, but also the purity referred to the total protein in the sample. For many authors, the latter is the preferred parameter to report sample's purity (Konrad \& Kleinschmidt, 2008; Tarhan \& Harsa, 2014). In the particular case of $\alpha$-LA nanotubes, the presence of low concentrations of other proteins may lead to amorphous structures or aggregates (GravelandBikker \& de Kruif, 2006; Tarhan \& Harsa, 2014). $\alpha$-LA purity (based on total protein) in peak 1 was $92.93 \pm 3.29 \%$ (Table 2 ), which should be high enough for a proper nanotube formation. This will be addressed in the next section.

Considering that $\alpha$-LA purity (based on total protein) in crude WPI was $12.15 \pm 0.46 \%$, the PF (purification factor) for $\alpha$-LA was $7.65 \pm 0.40$ in peak 1 (Table 2). The PF for $\beta$-LG in peak 3 was slightly lower $(1.49 \pm 0.10)$, as $\beta$-LG purity (based on total protein) in the crude WPI was higher $(70.47 \pm 2.49 \%$, Table 2$)$.

\subsection{Nanotube synthesis from purified fractions}

$\alpha$-LA samples from the previous purification on a $98 \mathrm{~mL}$ DEAE-S FF gel column (peak 1 and peak 2) were used to synthesise nanotubes. Also, crude WPI and commercial $\alpha$-LA from Davisco were used for comparative purposes.

After a 3-h gelation process, the gels obtained with $\alpha$-LA from Davisco and peak 1 were the strongest and most transparent gels; and gels obtained with crude WPI were the most opaque and weakest. These results agree with the micrographs obtained by TEM (Fig. 6). In WPI samples no nanotubes were formed, and protein aggregates appeared instead. In peak 2 samples nanotubes were formed, but they were irregular, short, and surrounded by random aggregates. In peak 1 samples nanotubes were correctly formed, however, the nanotube density was lower than that obtained with $\alpha$-LA from Davisco (Fig. 6).

Although solute concentration was $30 \mathrm{mg} \mathrm{mL}^{-1}$ in all the reactions, $\alpha$-LA concentration varied from sample to sample depending on their purity (based on total solute) (Table 2). It was $3.17 \pm 0.10 \mathrm{mg} \mathrm{mL}^{-1}$, $23.47 \pm 0.80 \mathrm{mg} \mathrm{mL}^{-1}$ and $18.20 \pm 0.83 \mathrm{mg} \mathrm{mL}^{-1}$ in WPI, peak 1 and peak 2, respectively. Graveland-Bikker et al. (2006) determined the minimum $\alpha$-LA concentration at which nanotubes are formed. They estimated that $20 \mathrm{mg} \mathrm{mL}^{-1}$ was enough to allow nanotube synthesis but more slowly than at $30 \mathrm{mg} \mathrm{mL}^{-1}$. This could explain the different nanotube density found in peak 1 samples when compared to that obtained with $\alpha$-LA from Davisco (Fig. 6). $\alpha$-LA purity in peak 1 (based on total protein) was high enough (92.93 $\pm 3.29 \%-$ Table 2$)$, to allow a correct nanotube formation. However, in the nanotube synthesis, $\alpha$-LA concentration was lower in peak 1 sample than in the standard sample ( $\alpha$-LA from Davisco). Therefore, considering that all the samples were taken at the same gelation time $(3 \mathrm{~h})$, the lower nanotube density in peak 1 samples was most likely caused by a nanotube formation rate limited by low $\alpha$-LA concentration.

Besides the $\alpha$-LA concentration, the presence of other contaminating proteins is also critical in the formation of nanotubes. Graveland-Bikker and de Kruif (2006) described the consequences of introducing different percentages of $\beta$-LG in the $\alpha$-LA nanotubes synthesis while keeping the total protein concentration at $30 \mathrm{mg} \mathrm{mL}^{-1}$. The occurrence of random aggregates was already favoured with only $2 \%$ of $\beta$-LG. This could explain the absence of nanotubes in the case of WPI samples, which contained $70.47 \pm 2.49 \%$ of $\beta$-LG and $2.17 \pm 0.67 \%$ of BSA (Table 2), and also the nanotube malformation with random aggregates in the peak 2 sample, with $11.18 \pm 4.61 \%$ of $\beta$-LG and $14.47 \pm 4.61 \%$ of BSA.

\section{Conclusions}

The developed purification method allowed obtaining acceptable yields of highly pure $\alpha$-LA and $\beta$-LG samples ( $>90 \%$, based on total protein) from WPI with purification factors of 7.7 and 1.5, respectively. It was possible to obtain two valuable proteins using a simple one-step chromatographic purification process. The purest $\alpha$-LA samples were 


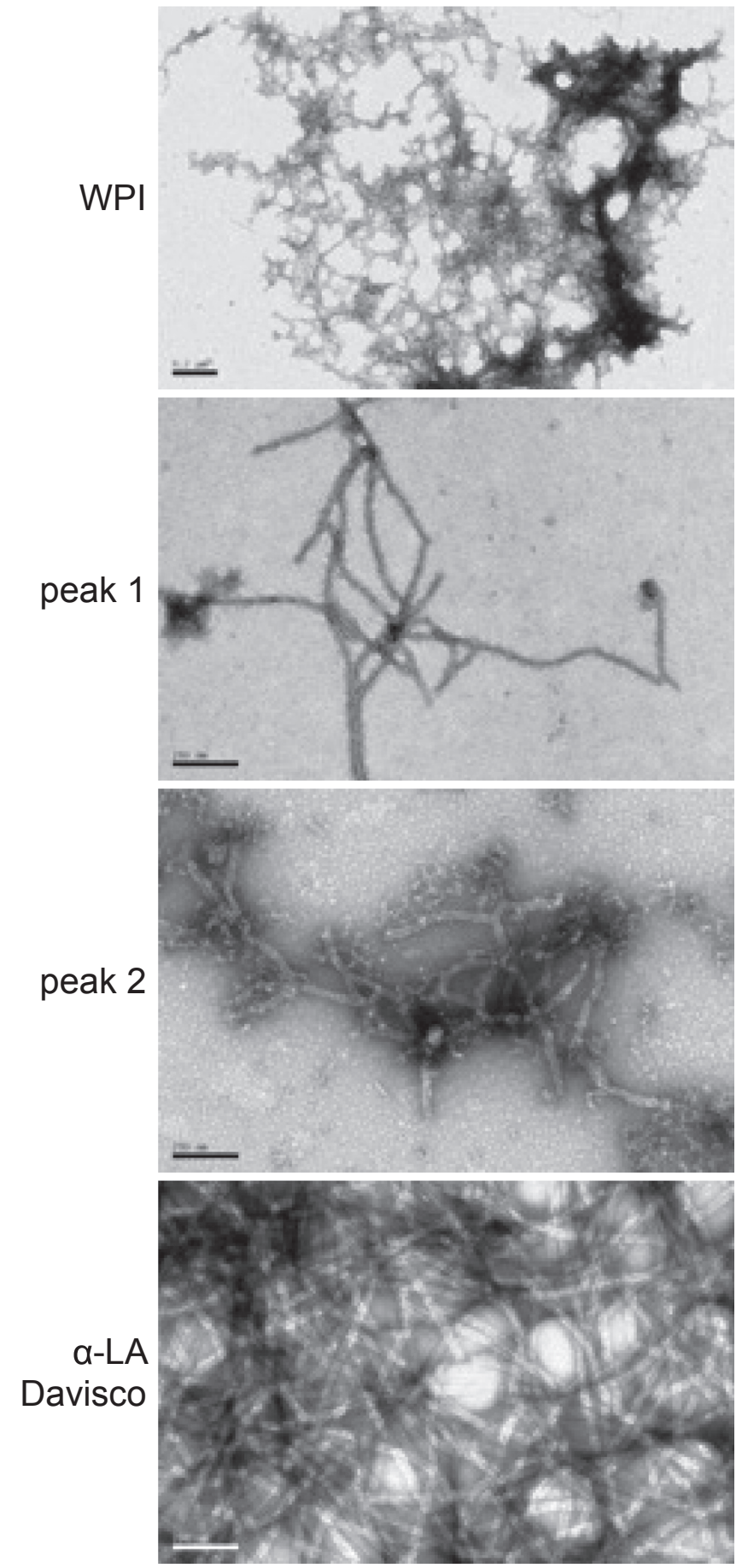

Fig. 6. Transmission electron micrographs (TEM) of gels obtained with $30 \mathrm{~g} \mathrm{~L}^{-1}$ of WPI, pure $\alpha$-lactalbumin ( $\alpha$-LA) from Davisco, and fractions (peak 1 and peak 2) purified from whey protein isolate (WPI) by AEC on a $98 \mathrm{~mL}$ DEAES FF gel column. Gelation conditions: incubation in $75 \mathrm{mM}$ Tris- $\mathrm{HCl}(\mathrm{pH} 7.5)$ with $4 \% \mathrm{BLP}(\mathrm{w} / \mathrm{w}, \mathrm{BLP} / \alpha-\mathrm{LA})$ and $2.79 \%(\mathrm{w} / \mathrm{w}) \mathrm{MnCl}_{2} \cdot 4 \mathrm{H}_{2} \mathrm{O}$, during $3 \mathrm{~h}$ at $55{ }^{\circ} \mathrm{C}$. The scale bar represents $200 \mathrm{~nm}$.

also useful to synthesise food-grade nanotubes. The gels obtained with these samples were strong and transparent, which are good qualities for using them as a food thickener. Cheese industries can find in this work an innovative solution whereby the residual milk whey is reused by developing new products with high added value.

\section{Acknowledgements}

Clara Fuciños gratefully acknowledge her Postdoctoral grant (I2C 2014) from Consellería de Cultura, Educación e Ordenación Universitaria (Xunta de Galicia, Spain). This study was supported by the Portuguese Foundation for Science and Technology (FCT, Portugal) under the scope of the strategic funding of UID/BIO/04469/2013 unit and the Project RECI/BBB-EBI/0179/2012 (FCOMP-01-0124-FEDER027462).

\section{References}

Alomirah, H. F., \& Alli, I. (2004). Separation and characterization of ß-lactoglobulin and a-lactalbumin from whey and whey protein preparations. International Dairy Journal, 14(5), 411-419.

Arunkumar, A., \& Etzel, M. R. (2014). Fractionation of a-lactalbumin and ß-lactoglobulin from bovine milk serum using staged, positively charged, tangential flow ultrafiltration membranes. Journal of Membrane Science, 454, 488-495.

Bonnaillie, L. M., \& Tomasula, P. M. (2012). Fractionation of whey protein isolate with supercritical carbon dioxide to produce enriched alactalbumin and ß-lactoglobulin food ingredients. Journal of Agricultural and Food Chemistry, 60(20), 5257-5266.

Brody, A. L., Bugusu, B., Han, J. H., Sand, C. K., \& McHugh, T. H. (2008). Innovative food packaging solutions. Journal of Food Science, 73(8), R107-R116.

Cetinkaya, S., \& Akkaya, B. (2016). Selective and single step adsorption of a-lactalbumin from whole cow's milk on hydroxyapatite microbeads. Materials Science and Engineering $C, 68,573-578$.

Croguennec, T., O'Kennedy, B. T., \& Mehra, R. (2004). Heat-induced denaturation/aggregation of ß-lactoglobulin A and B: Kinetics of the first intermediates formed. International Dairy Journal, 14(5), 399-409.

El-Sayed, M. M. H., \& Chase, H. A. (2010). Purification of the two major proteins from whey concentrate using a cation-exchange selective adsorption process. Biotechnology Progress, 26(1), 192-199.

Estévez, N., Fuciños, P., Bargiela, V., Picó, G., Valetti, N. W., Tovar, C. A., et al. (2017). Influence of $\mathrm{pH}$ on viscoelastic properties of heat-induced gels obtained with a $\beta$ Lactoglobulin fraction isolated from bovine milk whey hydrolysates. Food Chemistry, 219, 169-178.

FAO (2013). FAO statistical yearbook 2013. World Food and Agriculture. Rome (Italy): Food \& Agriculture Organization of the United Nations (FAO).

Fuciños, C., Míguez, M., Fuciños, P., Pastrana, L. M., Rúa, M. L., \& Vicente, A. A. (2017). Creating functional nanostructures: Encapsulation of caffeine into a-lactalbumin nanotubes. Innovative Food Science and Emerging Technologies, 40, 10-17.

Geng, X. L., Tolkach, A., Otte, J., \& Ipsen, R. (2015). Pilot-scale purification of a-lactalbumin from enriched whey protein concentrate by anion-exchange chromatography and ultrafiltration. Dairy Science and Technology, 95(3), 353-368.

Graveland-Bikker, J. F., \& de Kruif, C. G. (2006). Unique milk protein based nanotubes: Food and nanotechnology meet. Trends in Food Science and Technology, 17(5), 196-203.

Graveland-Bikker, J. F., Fritz, G., Glatter, O., \& De Kruif, C. G. (2006). Growth and structure of $\alpha$-lactalbumin nanotubes. Journal of Applied Crystallography, 39(2), $180-184$.

Graveland-Bikker, J. F., Ipsen, R., Otte, J., \& De Kruif, C. G. (2004). Influence of calcium on the self-assembly of partially hydrolyzed $\alpha$-lactalbumin. Langmuir, 20(16), 6841-6846.

Guimarães, P. M. R., Teixeira, J. A., \& Domingues, L. (2010). Fermentation of lactose to bio-ethanol by yeasts as part of integrated solutions for the valorisation of cheese whey. Biotechnology Advances, 28(3), 375-384.

Ipsen, R., \& Otte, J. (2007). Self-assembly of partially hydrolysed $\alpha$-lactalbumin. Biotechnology Advances, 25(6), 602-605.

Konrad, G., \& Kleinschmidt, T. (2008). A new method for isolation of native a-lactalbumin from sweet whey. International Dairy Journal, 18(1), 47-54.

Laemmli, U. K. (1970). Cleavage of structural proteins during the assembly of the head of bacteriophage T4. Nature, 227(5259), 680-685.

Liang, M., Chen, V. Y. T., Chen, H., \& Chen, W. (2006). A simple and direct isolation of whey components from raw milk by gel filtration chromatography and structural characterization by Fourier transform Raman spectroscopy. Talanta, 69(5), 1269-1277.

Lisak, K., Toro-Sierra, J., Kulozik, U., Bozanic, R., \& Cheison, S. C. (2013). Chymotrypsin selectively digests ß-lactoglobulin in whey protein isolate away from enzyme optimal conditions: Potential for native a-lactalbumin purification. Journal of Dairy Research, $80(1), 14-20$.

Mao, X., Zhang, G., Li, C., Zhao, Y., Liu, Y., Wang, T., et al. (2017). One-step method for the isolation of a-lactalbumin and ß-lactoglobulin from cow's milk while preserving their antigenicity. International Journal of Food Properties, 20(4), 792-800.

Morrissey, J. H. (1981). Silver stain for proteins in polyacrylamide gels: A modified procedure with enhanced uniform sensitivity. Analytical Biochemistry, 117(2), 307-310.

Neelima, Sharma, R., Rajput, Y. S., \& Mann, B. (2013). Chemical and functional properties of glycomacropeptide (GMP) and its role in the detection of cheese whey adulteration in milk: A review. Dairy Science and Technology, 93(1), 21-43.

Neyestani, T. R., Djalali, M., \& Pezeshki, M. (2003). Isolation of a-lactalbumin, ß-lactoglobulin, and bovine serum albumin from cow's milk using gel filtration and anionexchange chromatography including evaluation of their antigenicity. Protein 
Expression and Purification, 29(2), 202-208.

Pilbrow, J., Bekhit, A. E. A., \& Carne, A. (2016). Fractionation of sheep cheese whey by a scalable method to sequentially isolate bioactive proteins. Food Chemistry, 203, 165-174.

Ramos, O. L., Pereira, R. N., Martins, A., Rodrigues, R., Fuciños, C., Teixeira, J. A., et al. (2017). Design of whey protein nanostructures for incorporation and release of nutraceutical compounds in food. Critical Reviews in Food Science and Nutrition, 57(7), 1377-1393.

Sivakumar, K., \& Iyyaswami, R. (2015). Recovery and partial purification of bovine alactalbumin from whey using PEG 1000 - Trisdoium citrate systems. Separation Science and Technology (Philadelphia), 50(6), 833-840.

Tarhan, O., \& Harsa, S. (2014). Nanotubular structures developed from whey-based alactalbumin fractions for food applications. Biotechnology Progress, 30(6), 1301-1310.

Tolkach, A., Steinle, S., \& Kulozik, U. (2005). Optimization of thermal pretreatment conditions for the separation of native a-lactalbumin from whey protein concentrates by means of selective denaturation of ß-lactoglobulin. Journal of Food Science, 70(9), E557-E566.
Toro-Sierra, J., Tolkach, A., \& Kulozik, U. (2013). Fractionation of a-lactalbumin and ßlactoglobulin from whey protein isolate using selective thermal aggregation, an optimized membrane separation procedure and resolubilization techniques at pilot plant scale. Food and Bioprocess Technology, 6(4), 1032-1043.

Vázquez, J. A., Docasal, S. F., Prieto, M. A., González, M. P., \& Murado, M. A. (2008). Growth and metabolic features of lactic acid bacteria in media with hydrolysed fish viscera. An approach to bio-silage of fishing by-products. Bioresource Technology, 99(14), 6246-6257.

Walstra, P., Wouters, J. T. M., \& Geurts, T. J. (2006). Dairy science and technology (2nd ed.). Amsterdam, Nederlands: CRC Press Taylor \& Francis.

Weiss, J., Takhistov, P., \& McClements, D. J. (2006). Functional materials in food nanotechnology. Journal of Food Science, 71(9), R107-R116.

Yver, A. L., Bonnaillie, L. M., Yee, W., Mcaloon, A., \& Tomasula, P. M. (2012). Fractionation of whey protein isolate with supercritical carbon dioxide-process modeling and cost estimation. International Journal of Molecular Sciences, 13(1), 240-259. 